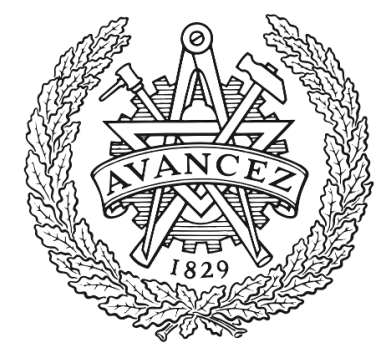

\title{
CHALMERS
}

UNIVERSITY OF TECHNOLOGY

\section{Doing strategy in project-based organizations: Actors and patterns of action}

Downloaded from: https://research.chalmers.se, 2023-04-26 13:08 UTC

Citation for the original published paper (version of record):

Löwstedt, M., Räisänen, C., Leiringer, R. (2018). Doing strategy in project-based organizations: Actors and patterns of action. International Journal of Project Management, 36(6): 889-898. http://dx.doi.org/10.1016/j.ijproman.2018.05.002

N.B. When citing this work, cite the original published paper. 


\title{
Doing strategy in project-based organizations: Actors and patterns of action
}

\begin{abstract}
In the project-management literature, projects have often been conceptualized as mere implementation sites of organizational strategy. However, such rationalization seldom draws on empirical evidence of strategy as it unfolds at the micro-level and at the interfaces between projects and the organization. Drawing on rich case-study data, this article explores strategy as-it-is-practiced in a large project-based organization. Using a Strategy-as-Practice lens to identify key patterns of strategizing actions, we found that project mind-sets and skillsets afforded project actors legitimacy to act as strategists on all organizational levels. Project actualities therefore broadly shape strategy in the organization, and play a much larger role in organizational strategizing than typically portrayed in the literature. The findings are used to suggest new perspectives regarding who are strategist and what strategy is in project-based organizations, and outline new directions for a revitalized research agenda on strategy in the project-management field.
\end{abstract}

\section{INTRODUCTION}

Although the importance of strategy for all levels of governance of a project-based organization (PBO) has been recognized, strategy remains a theoretical and methodological contested construct (e.g. Winter et al 2006; Greene et al 2008; Söderlund and Maylor 2012; Biesenthal and Wilden 2014). In the project-management literature, projects have often been conceptualized as merely being implementation sites of organizational strategy (the stable entity) rather than sites where actual strategizing activity may be carried out (Morris and Pinto 2004; Shenhar 2004; Morris and Jamieson 2005; Young et al. 2012). This view can be compared with the mainstream perspective of strategy 'as plan' (Mintzberg et al. 2005), whereby an organizational strategic plan is formulated at top-level and then governs what should be done at operational levels (Chandler 1962; Ansoff 1965; Porter 1996). There is a curious absence of human actors and their actions from such a perspective of strategy (Jarzabkowski and Spee 2009). Focusing on actors doing strategy a growing number of Strategy-as-Practice scholars ( $\mathrm{SaP}$ ) have shown that strategy is not a stable, homogeneous 
entity across contexts and times; it is a dynamic activity that is practiced and adapted to different contextual contingencies by different actors at different levels of an organization (e.g. Whittington, 2004; Jarzabkowski et al., 2007; Golsorkhi et al., 2010). It therefore makes sense to talk about strategizing alongside strategy (Jarzabkowski et al., 2007), and to assume that strategizing (activity) can take place at all levels in an organization, including project levels in PBOs.

A few scholars have critiqued the common top-down, one-dimensional standpoints of strategy in the project-management literature, calling for research into interrelationships between projects and their parent organization other than that of 'obedient servant' (Artoo et al 2008) or site of 'strategy execution only' (Söderlund and Maylor 2012). Examples of such research can be found in studies that highlight how strategic value diffuses upwards from the project to their parent organization rather than the other way around (see for example Martinsuo et al 2012, for a recent special issue). Such upward-flowing value streams may be more likely to be acknowledged for large (or mega) projects, the (economic) magnitudes of which make them strategically critical (e.g. Eweje et al., 2012). There are also examples of studies that show strategy as being formed by a combination of both bottom-up and top-down movements between the projects and their organizations (Srivannaboon and Milosevic 2006). The influential 'project capabilities view', for example, falls into this category, portraying strategic capabilities of PBO's as something that builds on continuous mixes of bottom-up learning from projects-to-organization and top-down strategic decision-making from organization-to-projects (e.g. Brady and Davies 2004; Davies and Brady 2016; Winch and Leiringer, 2016; Adam and Lindahl, 2017) The 'two interacting levels of learning' involved in the building of strategic project capabilities are thus the 'project' on the one hand, and the ‘organization' on the other (Brady and Davies 2004). 
While the aforementioned studies can indeed be seen as highlighting the active role that the project level may play in forming strategy in PBOs, they also exemplify a common tendency in project-management studies to give analytical and interpretative preference to project or/and organizational level abstractions when strategy is discussed. This tendency to understand strategy as something that is formed (or not) via various combinations of 'projects' and 'organization' interactions has, it seems, relegated the actual actors carrying out strategic activities at the micro level to the background. Indeed, even in those cases where the actor-level is in focus data collection tools are seldom geared towards, and interpretive priority is rarely given to the richness of their experiences and the complex social processes that underpin their day-to-day activities. Instead, research designs either privilege the use of pre-formulated hypotheses with data collected through Likert-type scales (e.g. Eweje et al 2012; Unger et al 2012; ul Musawir et al 2017) or obscure the actor-level within 'project' and ‘organization' level accumulations (cf. Brady and Davies 2004; Vouri et al 2012). The resilience of this strain of research is also reflected in the growing literature of Project Portfolio Management (PPM) and its relation to strategy in PBOs. In the majority of these studies, PPM is (pre)conceived as yet another analytical level portrayed as an intermediary between the 'project level' and the 'organizational level', or between 'business strategy' and 'project management' (e.g. Meskendahl 2010; Killen et al 2012; Kopmann et al 2017). This has led other scholars to raise concerns regarding the lack of practice-based studies of PPM in PBO’s (Martinsuo 2013), emphasizing the need to increase understanding of how the actors in PBOs actually work with strategy practices to actualize strategy.

The above line of reasoning around strategy practices echo recent calls for a stronger practice agenda in project management research in general. Cicmil et al (2006) and Blomquist et al 
(2010) among others make a strong case for the need to rethink project management research by adding fine-grained studies of the 'actualities of projects' i.e., the lived experiences of project managers and project members. We argue here that it is not only the actualities of projects per se that need to be uncovered, there is also an urgent need to understand the actualities of the interfaces at the levels between projects, project portfolios and the organization in increasingly complex PBOs (cf. Maylor et al 2006; Winch 2014; Söderlund et al 2014).

In line with Söderlund and Maylor's (2012) suggestion, we apply a Strategy-as-Practice (SaP) lens to explore patterns of strategizing in PBOs, focusing specifically on how various actors interact across the project-organization interface in order to negotiate and form strategy. Drawing on rich case-study data collected in a large PBO over several years we identify key patterns of organizational outcomes which permeate multiple organizational levels (strategizing). A central feature of these patterns is that project mind-sets and practices are strongly inculcated in the mind-sets and practices at the strategic levels. Following this we show how project actualities broadly shape approaches to strategy in the PBO we studied, and therefore play a much larger role in organizational strategizing than typically portrayed in the project-management literature. We conclude by problematizing some of the most fundamental issues regarding strategy-making as it emerges out of a project-based context (what is strategy and who are the strategists?) and outline new directions for a revitalized research agenda on strategy in the project management-field.

\section{THE STRATEGY-AS-PRACTICE PERSPECTIVE}


The origin of the Strategy-as-Practice (SaP) perspective coincides with the practice and linguistic turns (e.g. Schatzki et al., 2001; Alvesson and Kärreman, 2000) in the social sciences, being primarily concerned with how strategy is actually enacted on the micro-level of organizations (Tsoukas and Chia, 2002; Chia and Mackay, 2007; Golsorkhi et al., 2010). $\mathrm{SaP}$ advocates a shift in attention from the notion of strategy as something an organization has i.e., which exists per se, to something organizational members do (e.g. Whittington, 2004; Jarzabkowski et al., 2007; Johnson et al., 2007). As such, it is the dynamic processes, practices and activities i.e., emerging and integrating patterns top-down and bottom-up (cf. Mintzberg and Waters, 1985), that are privileged, rather than ideal states, end-products, or formal pre-defined organizational levels such as 'project' and 'organization'. Strategizing, therefore, describes a constant and emerging organizational becoming (cf. Tsoukas and Chia, 2002; Winter et al., 2006). This is the ontological, as well as the analytical, priority of a SaP perspective.

Strategizing can be defined as the intra-organizational work required from emergence to execution of strategies (Jarzabkowski et al., 2007), including the project level. Strategizing actions and discourse emerge in top-down and bottom-up negotiations that disperse onto various organizational levels, linking micro-level practices with outcomes on various macrolevels (Jarzabkowski et al., 2007; Johnson et al., 2007; Golsorkhi et al., 2010). Strategizing is the pattern of a socially accomplished activity that unfolds when strategy practitioners draw on strategy practices (Jarzabkowski et al., 2007). Certain 'traditional' strategy practices could be considered as central elements for strategizing insofar as their activities could be linked to those social patterns emerging as organizational outcomes and directions. However, in regard to the common 'strategy as planning' perspective (e.g. Mintzberg et al., 2005), SaP draws on a growing understanding within the strategic management field that strategy very seldom is 
accomplished in practice as it is formulated in a deliberate pre-established and formalized strategy plan - regardless of type of industry or organizational form (e.g. Mintzberg and Waters, 1985). Instead, the notion of strategy as 'emerging patterns of actions' has gained currency within $\mathrm{SaP}$ (e.g. Whittington, 2007), and includes activities that may not seem directly related, or may be only loosely linked to the plan. Likewise, a strategic activity may fail to achieve the intended strategic outcome for a variety of reasons.

$\mathrm{SaP}$, as we see it, is a methodological perspective rather than a theory per se. It can be carried out using a wide variety of theoretical lenses and data collection and analysis tools (cf. Golsorkhi et al., 2010), and is characterized less by what theory is being used than by what problem is explored and approach taken (Jarzabkowski et al., 2007). In this article, the problem is how micro-level practices can be linked to outcomes on various organizational levels in a large PBO, and the approach is to foreground the perceptions and actions of the actors who engage in the actualities at hand rather than à priori superimposing a preconceived framework, model, or levels on the exploration. Thus, we respond to the calls of Floricel et al. (2014), Blomquist et al. (2010) and Cicmil et al. (2006) for more practice-oriented research in the field of project management. In this sense, a SaP perspective recognizes as the unit of analysis the specific situated practices that actors in PBOs may be drawing on when doing strategy-related work, especially the activities and practices they themselves label as strategic and which are directed toward fulfilling an organizational goal.

Through the 'strategy as planning' perspective, strategy has long been seen as an activity that is privileged to top-management in an organization (cf. Chandler 1962; Ansoff 1965; Porter 1996.). This view resonates with much of the project-management literature in which top management formulate strategy and project operatives abide by, and merely execute, the plan 
(e.g. Artto et al. 2008; Winter et al 2006; Söderlund and Maylor 2012). As Morris and Jamieson (2005) point out the PMBOK Guide (Project Management Institute 2004) assumes no real involvement of project management in strategy formulation and planning. Rather, the large number of studies using the PMBOK as a normative guide have diffused the notion that project managers have no involvement in strategy work. However, from a SaP perspective strategists are not defined in terms of a formal position, but rather in terms of the kinds of activities they carry out at specific points in time. In other words, strategists are those who carry out activities which lead to (strategic) outcomes (Whittington 2006) during and after the deployment of such activities. When they are not carrying out these activities, they are no longer strategists; they take on some other role. Thus, SaP scholars look for strategists beyond top-managers, and expect to find them in other positions and spaces (Jarzabkowski et al., 2007). These positions range from the top to lower-level managers, including middle managers that engage in strategy not only through execution and implementation, but through top-down and bottom-up processes of agenda seeking, proposal selection and information filtering (e.g. Mantere, 2008); as well as employees, who are identified as strategy makers in the 'periphery' (Regnér, 2003). External actors, such as strategy consultants, may also act as organizational strategists (Whittington 2006). This means that rather than separating the roles of strategists and project managers when studying strategizing in $\mathrm{PBOs}$, a SaP perspective recognizes the project manager as a potential strategist in his/her own right (cf. Söderlund and Maylor 2012).

\section{CASE DESCRIPTION AND RESEARCH DESIGN}

The data upon which this article draws comes from a longitudinal (2010-2015) case study conducted in the Swedish Business Unit of a large multi-national construction company. The 
company is, like most other large construction companies, a typical PBO, operating under a matrix business structure, in which a fair amount of decision-making power is delegated to the project levels. It employs approximatively 60.000 people worldwide, making it one of the largest companies of its kind. The Swedish Business Unit (from here on referred to as ConstCorp) has close to 10.000 employees and is one of the three largest contractors on the Swedish market. It too operates under a de-centralized operating structure and at the heart of the business is the building and infrastructure projects for which a seemingly one-of-a-kind temporary organization is set up at different geographical locations for each new endeavour. ConstCorp performs hundreds of these projects every year, with order values typically ranging somewhere between 10-100 million (EUR).

The original premise of the study was to move away from the project as the unit of analysis to instead explore aspects of strategy and governance more broadly. Little did we know then how central a role the project levels would play in shaping the approach to strategy in the organization. A SaP lens was considered well-suited as we wanted to examine situated practices rather than generic and espoused frameworks. The purpose of the study as a whole was thus to examine in-depth the social patterns of strategizing and the links to organizational outcomes over time in construction companies, i.e., how strategizing at the micro-level influenced macro-level practices and outcomes, and vice versa (cf. Johnson et al., 2007; Jarzabkowski et al., 2007). In this article, we draw on the case study data to offer rich descriptions of how these social patterns unfold.

In trying to capture the complex patterns of strategizing as they unfold top-down and bottomup at multiple organizational levels, we studied a wide variety of different practices and practitioners, located, and operating, across the whole of ConstCorp. Table 1 below provides 
an overview of the three sub-studies that make up the data collected over a period of five years (2010-2015). In study A, in-depth open-ended interviews were used to elicit life-story accounts from 27 managers from a broad variety of organizational levels and functions to gauge their experiences and interpretations of change within the organization over the past 20 years or during their employment. Note that in these interviews we did not mention the term 'strategy' and instead let the respondents decide which changes were important and offer their own interpretations of underlying reasons for these changes, or indeed non-change, over time.

Study B comprised field observations in a series of strategy workshops led by external management consultants. It also encompassed managers at all levels of the organization (top, middle and project) and provided us with invaluable cross-level insight of strategy as practiced. Study C was a short, four-week, ethnographic study in which the first author worked as a 'dog's body' on a construction site in order to capture the interplay and influence of the parent organization on the day-to-day practices at the project level.

Table 1. Overview case study ConstCorp

\begin{tabular}{|c|l|l|l|}
\hline $\begin{array}{c}\text { Study/period of } \\
\text { time }\end{array}$ & Study A 2010 & Study B 2011 and 2013 & Study C 2014 \\
\hline Focus & $\begin{array}{l}\text { Dominant organizational } \\
\text { practice and logic }\end{array}$ & $\begin{array}{c}\text { Strategy practice in-use } \\
\text { (strategy workshops) }\end{array}$ & $\begin{array}{l}\text { Project practice in-use } \\
\text { (construction project) }\end{array}$ \\
\hline $\begin{array}{c}\text { Organizational } \\
\text { level }\end{array}$ & Multiple organizational levels & Multiple organizational levels & Project levels \\
\hline Method used & Open-ended interviews & Observations & Ethnography \\
\hline
\end{tabular}




\begin{tabular}{|c|c|c|c|}
\hline $\begin{array}{l}\text { Practitioners } \\
\text { included }\end{array}$ & $\begin{array}{l}27 \text { interviews } \\
\text { High-, middle-, and project } \\
\text { level managers', covering both } \\
\text { central and geographically } \\
\text { distributed units } \\
1 \text { HR manager } \\
6 \text { regional managers } \\
8 \text { district managers } \\
3 \text { project managers } \\
1 \text { economy manager } \\
2 \text { market managers } \\
1 \text { supply manager } \\
3 \text { strategy group members } \\
1 \text { environmental manager }\end{array}$ & $\begin{array}{l}9 \text { full days of workshop } \\
\text { activities were observed } \\
1 \text { group with } 10 \text { high level } \\
\text { managers ( } 3 \text { days) } \\
1 \text { group with } 20 \text { district } \\
\text { managers ( } 3 \text { days) } \\
1 \text { group with } 20 \text { project } \\
\text { managers' ( } 3 \text { days) } \\
5 \text { strategy consultants }\end{array}$ & $\begin{array}{l}\text { Researcher spent } 4 \\
\text { weeks on site at a } \\
\text { construction project } \\
\text { of } 40 \text { residential } \\
\text { apartments divided } \\
\text { between two } \\
\text { buildings. Working } \\
\text { alongside } 1 \text { project } \\
\text { manager, } 3 \text { assistant } \\
\text { project managers, and } \\
40 \text { construction } \\
\text { workers }\end{array}$ \\
\hline Data overview & $\begin{array}{l}1-2 \text { hours /interview } \\
\text { audio recorded, transcribed } \\
\text { verbatim (between } 10-12 \\
\text { pages per interview and close } \\
\text { to } 300 \text { pages in total) }\end{array}$ & $\begin{array}{l}100 \text { pages of written field } \\
\text { notes / written visions and } \\
\text { goals, planning } \\
\text { documentation, workshop } \\
\text { handouts: agendas, } \\
\text { presentations slides, group } \\
\text { exercises, summary group } \\
\text { exercises } \\
5 \text { follow-up interviews with } \\
\text { participants from the strategy } \\
\text { workshops (1 year after the } \\
\text { occasion) }\end{array}$ & $\begin{array}{l}50 \text { pages of written } \\
\text { field notes / } \\
\text { pamphlets and } \\
\text { material collected } \\
\text { from the project } \\
\text { intranet/ } 300 \text { pictures } \\
\text { taken on site }\end{array}$ \\
\hline Miscellaneous & $\begin{array}{l}\text { Researcher spent time at one } \\
\text { of ConstCorp’s regional } \\
\text { offices. Informal } \\
\text { conversations/notes taken }\end{array}$ & $\begin{array}{l}\text { Researchers participated in } \\
\text { informal conversations. Sat in } \\
\text { on all breakfasts, lunches, } \\
\text { dinners, and after work beers, } \\
\text { with the managers during the } \\
\text { workshop days/notes taken }\end{array}$ & $\begin{array}{l}\text { Researcher } \\
\text { participated in } \\
\text { informal } \\
\text { conversations. Sat in } \\
\text { on all breakfasts, } \\
\text { lunches, breaks /notes } \\
\text { taken }\end{array}$ \\
\hline $\begin{array}{l}\text { Analysis and } \\
\text { theoretical lens }\end{array}$ & $\begin{array}{l}\text { Narrative approach and } \\
\text { analysis (Czarniawska, 2004) } \\
\text { to elicit a 'dominant narrative' } \\
\text { (Isabella 1990) of } \\
\text { organizational life across } \\
\text { multiple organizational levels }\end{array}$ & $\begin{array}{l}\text { Bourdieu's practice theory } \\
\text { lens (Bourdieu, 1990) used to } \\
\text { frame the interaction between } \\
\text { two different habitual groups } \\
\text { engaging in a common } \\
\text { strategy practice }\end{array}$ & $\begin{array}{l}\text { A self-reflexive } \\
\text { ethnographic lens } \\
\text { (Alvesson et al., } \\
\text { 2008) } \\
\text { used to elicit the } \\
\text { interplay and } \\
\text { influence of } \\
\text { organizational }\end{array}$ \\
\hline
\end{tabular}

\footnotetext{
${ }^{1}$ The project manager role we refer to in this article is also commonly referred to as 'site manager' in the construction industry. They serve as the project managers during the production phases and thus occupy a position which strongly affects the performance of construction projects (see for example Styhre 2006 for a more detailed description of this role)
} 


\begin{tabular}{|c|c|c|c|}
\hline & & & $\begin{array}{l}\text { routines on day-to- } \\
\text { day project practices }\end{array}$ \\
\hline $\begin{array}{c}\text { More detailed } \\
\text { accounts }\end{array}$ & (Löwstedt and Räisänen 2012) & (Räisänen and Löwstedt 2014) & (Löwstedt 2015) \\
\hline
\end{tabular}

All the interviews were audio-recorded and transcribed verbatim and all the observations were recorded in extensive field notes, covering approximately 300 pages of text. Throughout the research project all data have been subjected to in-depth analysis using different methods and theoretical lenses: a narrative lens (Study A), Bourdieu's practice lens (Study B) and an ethnographic lens (Study C). The emerging findings have been presented and discussed with scholars in management, project management, and construction management at international conferences and the results of each individual study have been published in peer-reviewed journals (see references to "more detailed accounts" in Table 1).

In this article, our aim is to synthesize all the data to contribute with new insights on strategizing and project organizing. Our focus is a multi-level perspective. Drawing on a number of illustrative data snapshot we discuss and link together activities at different organizational levels. When relevant to provide more depth, we complement these snapshots with references to instances that include richer data descriptions. Combining insights from multiple organizational levels and synthesizing findings based on several theoretical and methodological approaches does not merely bring an advantage in term of triangulating the findings, but also resonates with a SaP view of strategy practice as a reciprocal accomplishment between the local strategizing situation and the wider social context in which it takes place (Seidl and Whittington, 2014). For instance, organizational narratives provide a 
valuable complement to observations of practice in regard to linking the local (micro) with the larger context (macro) (ibid.). From a SaP view, strategy practice can de facto be seen as being intimately tied to the local production and consumption of organizational narratives (Fenton and Langley, 2011). Combining the insights from the interview study (Study A) thus provided us with a broader contextual understanding of those interpretations and practices observed in Study B and Study C respectively (and vice versa).

Following a brief background of strategy work in ConstCorp, we present our findings sorted into four episodes/parts which together highlight the dimensions and the mechanisms of the strategizing pattern found. First, we present examples of mainstream strategy practices deployed at the project levels and highlight the characteristics of ensuing struggles. Second, we illustrate how dominant project practices can be seen as permeating all the organizational levels in ConstCorp forming a collective and broad approach towards strategy. In the third part we highlight the social processes underlying these observations and the particular mechanisms at play. We argue that the projects form the heartland of the organization and as such provide the foundation for the companywide strategizing. Finally, we provide accounts from those organizational members that stand outside of these heartlands in order to further explicate their nature and implications for strategizing in ConstCorp.

\section{RESULTS: PATTERNS OF ACTIONS IN A PBO}

Prior to the 1990's ConstCorp was organized in geographical units that operated independently of each other with few, if any, common strategic guidelines. ConstCorp was depicted as driven by the opportunistic endeavours of a number of 'mavericks' and 'project barons' (cf. Gann et al 2012). The common background of these individuals was construction; their formal and practical schooling was in civil engineering, and they had started their 
careers on construction sites. This steeping in a common initial community of practice, which has remained fairly constant over time in the construction industry, and which its members profess to be unique, has inculcated a strong collective identification in its members. Thus, the ideal ConstCorp employee is one that was initially fostered on site, in the dirt of the project.

These project barons, then, ran their projects and business units (with their project portfolios) independently, no questions asked, as long as they could deliver profits to ConstCorp. The organization, as most contractors in Sweden at the time, had no formulated company-wide strategy. However, at the end of the 1990s there was a change. Top management, under a new CEO, decided that ConstCorp had to increase its efficiency at the project levels by increased organizational centralization and standardization. As a result, in the beginning of the 2000's, top-management decided to recruit strategy specialists to enhance the organization's strategic capabilities. According to the common practice of strategic planning, top-management together with these designated strategy specialists formulated 30 strategies with subordinate action points for implementation downstream in the organization and the projects. The main difficulty during this strategy endeavor was to involve the project levels in the strategy work; a problem that the organization variously struggled with for almost to a decade.

In 2010, top management decided to launch a series of strategy workshops to further standardize strategic and operational processes. The decision was taken on the basis that the strategy initiatives carried out over the past years had failed to realize the overarching goals, i.e., to improve project performance. The planned workshops became a wide-ranging strategy initiative and a major endeavor in the company. The CEO decided that the strategy workshop was to be mandatory for all managerial levels, including project managers. The workshops, 
which took the form of three away-days, were designed and facilitated by a group of external management consultants (i.e. strategy experts), who had vast experience from running these types of workshops in many different industrial sectors. This was, however, their first encounter with the construction industry. They arrived at ConstCorp with a standard repertoire of established academic strategy tools, models and rhetoric. Part of their agenda during the workshops was to introduce two models relating to strategic analysis and assessment, namely the 'Importance-performance matrix' (see Slack and Lewis 2002:179) and the 'Operations-Strategy Matrix' (see Slack and Lewis 2002:283). Their intention was to 'teach' the managers at ConstCorp how to integrate these strategy-based models into their day-to-day practices.

\section{Patterns of action: Project level}

"We don't have the luxury to sit down and do all this thinking...we are doers you know...we just cut to the chase and do" [Project manager].

This quote epitomizes the often overtly aggressive utterances that the strategy consultants faced while interacting with the group of project managers during the strategy workshop. The 'valuable strategy tools' in the form of the two generic models mentioned above were vehemently resisted and demonstratively disregarded. The project managers firmly and collectively resisted the notion of sitting down and doing "all this analysis" and instead they explained that they relied on a more pragmatic ad-hoc problem-solving approach in their roles. The management consultants struggled to get their message across and were constantly attacked for the lack of relevance of their teachings to the actualities of the constructionrelated projects as experienced by the project managers. At one instance, in a moment of 
extreme frustration, the following illustrative exchange took place between the project managers and a consultant:

Project manager (1): We don't have any common standardized processes instead we are expected to solve problems as they arise.

Strategy consultant: Would you ... maybe ... call this to have strong reactive capabilities [the concept had just been defined by the consultants]

Project managers: [in unison] YES!

Project manager (2): I think we are generally fixated on solutions. We fix ... that is what we do, and it is in these temporal fixings that the shit hits the fan.

When the project manager uses 'we' in this exchange, he is, as we will argue in the next sections, referring to the collective 'we' of the construction industry, not only to project managers. The project managers goaded the consultants to use 'clear' and 'less academic' language and insisted that they translated terms such as, 'resource', 'capabilities', 'adjustments', 'operationalization', into their more pragmatic equivalents². To mock the consultants, they went to the other extreme, bringing up prosaic and very concrete day-to-day issues they dealt with:

Project manager 1: "I have quite a lot of problems with people that keep parking bicycles close to the construction sites [...] where does that fit [in the model]?" Project manager 2: "Yeah, and I would like to know what to do with all the manholes that were not included in the original drawings"

\footnotetext{
${ }^{2}$ For example, after a lot of back and forth bickering, the consultants unwillingly agreed that "operationalization" merely meant "to use something" and "organizational resources" merely meant "time and money" because "in the end it was all about time and money".
} 
Observing the strategy consultants and project managers discursive battling over incommensurate logics clarified the stark opposites at play as illustrated in table 2 below. On the one hand, there were the generic strategy practices evoked by the consultants, resting on the logic of proactive planning through analysis and organizational standardization; on the other there were project practices which rested on a reactive-oriented pragmatic problemsolving logic. This logic seemed to be deeply ingrained in the mind-set of all the project managers, resulting in an explicit collusion between the practitioners, unifying and strengthening their resistance.

\begin{tabular}{|ll|}
\hline strategy practices & project practices \\
\hline logic: proactive problem-solving & logic: reactive problem-solving \\
\hline method: formal analysis and planning & method: day-to-day pragmatism \\
\hline organization: standardized organizational processes & organization: ad-hoc, autonomy, individual skills \\
\hline
\end{tabular}

Table 2 Summary contrasting practices

The resistance to imposed strategy practices and the ensuing turbulence in the project managers' workshop contributed to the failure of the costly strategy-development project initiated by top-management. Of the 30 planned and booked three-day workshops only seven were carried out before the initiative was aborted.

Combining these observations with the findings from Study $\mathrm{C}$ show that these particular project practices were not evoked for the sake of forming resistance as such, but were indeed embedded in the realities that these project managers lived in their projects. Or put differently, pragmatic and reactive problem-solving seemed to be an institutionalized practice enabling 
individuals to deal with the high degree of complexity and unpredictability that characterizes construction projects. From Study C we learned that the aversion towards 'sitting down' to 'do thinking' in advance was, if anything, considered a waste of time, as no formal plans could ever 'catch up' with the complex realities of these projects anyways (see also Löwstedt 2015). At the occasion when being on site of one of ConstCorp's construction projects we asked the project manager to elaborate on his role and his practices:

$$
\begin{aligned}
& \text { My job is to 'fight fires' ... it is impossible to plan ahead for everything that is going } \\
& \text { to happen ...when 'the shit hits the fan', and it always does, all you can do is try to } \\
& \text { solve it the best you can [project manager] }
\end{aligned}
$$

This echoes exactly the observation from the strategy workshops (even in regard to the specific metaphor used).

\section{Patterns of action: Organizational level}

The decision to abort the workshop initiative prematurely was not merely based on the outcome from the sessions with the project managers, but on a collective resistance across all the managerial levels. The particular flavor and script of the workshop with the project managers closely resembled those at the higher levels of the organization. We observed and recorded the same resistance and complaints in the other two workshops we observed with organizational mid- and top-level managers: namely that 1) the consultants were 'too academic' and the knowledge and information they were attempting to convey were too abstract to carry relevance for the strategizing needs of the different levels of the PBO and the industry; 2) both at top-levels and middle-levels, we discerned an overt antipathy for, or at least an impatience with, meticulous and detailed pro-active planning based on possible 
futures; 3) the practitioners, on all organizational levels, wanted to 'cut to the chase and do', they were 'doers' and 'problem-solvers', not 'thinkers' and 'speculators' (see also Räisänen and Löwstedt 2014).

The business consultants, however, came from a very different background, with a very different mind-set, and were incapable of understanding how these managers saw the world. In the interview study (Study A), a top-level manager, described this world in the following words.

We are driven by a sense of urgency... it is very easy in ConstCorp to drive organizational change in times of crises and very hard otherwise ... I often say that we play 'back-spin balls' in ConstCorp... we play defence ... we play a boring game, but we play it well. [top-level manager]

To play "back-spin balls" is a sport metaphor that means to play safe and react to what the opponent does, i.e., wait for situations to arise and only then react, rather than predicting or averting them. Hence, when the strategy consultants picked up on 'reactive capabilities' in the workshop with the project managers, they in fact pinpointed a logic that regulated organizational life in ConstCorp more broadly (see Löwstedt and Räisänen 2012, for a detailed account of the dominant narrative that permeated all the organizational levels).

\section{Patterns of action: Projects as organizational heartlands}

An interesting pattern of action manifested in our data was the social capital that a construction background and education afforded our respondents. The vast majority of our interviewees, workshop participants and employees on the construction site, had a vocational 
or a higher degree in civil-engineering. Of particular note is that they started their careers in construction working on construction projects and showed pride in this origin. Even those at the highest managerial positions in the organization - positions that could easily be attributed to many other personal and professional traits - voiced pride in having 'cut their teeth' working on construction projects from whence they acquired the 'proper' mind-set and skillset necessary for all positions in a construction organization. The dominant logic in ConstCorp was, thus, that having 'the right' project mind-set and skillset was crucial not only to be a successful project manager, but was also the ideal profile for any other position in the organization (Räisänen and Löwstedt 2014).

An episode from the strategy workshop elucidates particularly well how deeply entrenched these ideas were. During a group discussion organized by the strategy consultants, a group of regional-level managers were discussing the difficulties of recruiting 'the right people' to the sales unit (doing economy-related calculus). One of the authors of this article joined the conversation:

Manager: It is very hard to find a good construction worker and then teach him [sic] to deal with numbers.

Author: Why don't you find someone that already knows how to deal with numbers and instead teach them about construction projects?

Manager: [long pause] That possibility never occurred to me. 
When the manager referred to 'a good construction worker', he was alluding to the project level as the location for his search, since project workers already had organizational legitimacy. The comment from the author was not meant to provoke, but merely point out a missed opportunity that seemed obvious from an outsider's perspective. However, the manager's reaction revealed the profound affiliation with the projects as the organizational heartlands, despite his high position.

\section{Patterns of action: The plight of the 'outsiders within'}

The deeply embedded idea of projects as the quintessence of organizational legitimacy was, however, never as evident as when articulated by those few individuals in ConstCorp that happened to stand outside. In Study A we interviewed three managers that worked in the designated strategy unit in ConstCorp. They had been appointed as, and formally named, 'strategists' to work with strategy, and had been hired from outside of the construction industry based on their particular skills and experiences relating to strategy work. During the interviews, these individuals clearly articulated how strategic management related to the overall organizational trajectory. They expressed awareness of the stark contrast between the logic they inscribed to strategy and the general perceptions of managers in ConstCorp. Yet, while they acknowledged the existence of the collectively preserved reactive-driven organizational identity highlighted in the sections above, they actively distanced themselves from it:

Yeah, you know, our organizational development is reactive and driven by adaptations. For example, we adapt to the market: Oh, did the cost of materials increase? Let's do something about it! [ironic tone] or: Oh, the subsidies have been withdrawn! So, let's do something! [ironic tone]. It 
is, you know, mostly reactive moves. Instead of being an organisation with a vision of the future and a direction that can take us there [strategist $\mathrm{A}]$.

In line with our previous reasoning they too attributed this organizational behaviour to the close connection to, and identification with, projects and the associated project mentality that most ConstCorp's managers, in their opinion, had. They also acknowledged that they did not share this connection to projects:

After 1.5 years in the organization I realized that I did not know about construction projects, so instead I concentrated on the things that I do know. I mean, $90 \%$ of the managers in this company know projects so bloody well! So why do I have to know it too? I mean, instead they should learn more of what I know rather than the other way around. But, they want me to learn projects, they want to cast me in the same mould because they believe that the key to success is that I know as much about construction projects as possible... and I don't have credibility as long as I don't. [strategist A]

What was clear was that these individuals perceived themselves as lacking legitimacy in the organization. This they attributed to a lack of project experience and to not having sufficient knowledge of project practices. Not having the right 'profile', they believed, marked them as outsiders in the organization. As one of them put it:

I have been told so many times that to get somewhere in ConstCorp I would need to go out and work on the construction projects for a while. [strategist B] 
This individual had recently been recruited to the strategy unit from outside construction and even though the prerequisites for the position were "competencies and experience of strategy work" rather than 'competencies and experience of construction project work' he still perceived himself as being tacitly marginalized. In contrast, those with prior project experience were deemed to be able to much quicker become a fully-fledged member of the collective and eligible for promotion much earlier. This situation was clearly frustrating for these formally appointed strategists, especially since they considered their work with strategy as being highly relevant for ConstCorp. From their perspective, the prevailing project-related mind-sets that was evident throughout the organization was merely a cultural burden inhibiting much needed strategy practices to be implemented and used.

\section{DISCUSSION}

Drawing on examples of typical patterns of actions uncovered in a longitudinal case-study of strategy as it is done in practice in a single PBO over a period of 5 years, we show how strong identification with projects creates a collective logic which permeate all organizational levels. This logic integrates the strategy-operations divide through its enduring affective and social ties to a common membership in a community of project workers. Employees possessing full legitimacy in ConstCorp were only those who had acquired experience from construction projects, and therefore shared pragmatic problem-solving capabilities and mind-sets. Topmanagers had started their careers on the projects and were fully aware of the project mindset, which is clearly shown in the result section. However, curtailing project managers' freedom and imposing rigid standards would probably be detrimental to project success. Top management therefore has to take the project characteristics into account in all its deliberations and decisions. 
The way that the managers collectively enacted a certain project mind-set could in Strategyas-Practice terms be characterized as strategizing patterns embedded in several organizational levels, creating significant organizational outcomes over time (Whittington, 2006; Chia and MacKay, 2007; Seidl and Whittington, 2014), whether intentional or not (e.g. Jarzabkowski et al., 2007; Golsorkhi et al., 2010). This we encapsulated in the dominant narrative of how things were done in ConstCorp, and how that was different from other industries and contexts (cf. Fenton and Langley, 2011). While this narrative circulated as a number of different metaphors and expressions, they all alluded to the same ingrained and dominant organizational logic that seemed to be central to the composition of organizational life and outcomes across organizational levels. This entails deploying a pragmatic and reactive-based problem-solving style, which is evident regardless if it is a project manager that is 'fighting fires' on the projects or a top-level manager 'playing back-spin balls' at higher organizational levels. This logic was also enacted to regulate the interactions with those that were 'outsiders' or at the periphery, be they strategy consultants or the small group of internal strategists (the outsiders on the inside) who lacked the apposite and preferred background of working on construction projects. All in all, this ingrained logic regulated the (lack of) implementation of 'imported' strategy practices as a means to ultimately improve project performance.

Who is then to be considered a 'strategist' in ConstCorp? There were indeed some actors who engaged in strategy in the traditional sense: some had developed and formulated strategy plans (often a CEO), some had commissioned strategy workshops as means to facilitate strategy-making and operationalizing the strategy plans on projects, and some had approved of hiring a group of designated strategists that were fully engaged in strategy related work. While they can be seen as the formal strategists, they were unable to contribute to the creation of significant organizational outcomes. Being empowered to do so was less about which 
formal role they had and more about being part of a certain informally structured community of practice. Those managers who had project experience and foregrounded its related practices and logics were collectively empowered to act as strategists. That is, they were

provided with the legitimacy to define what the 'real problems' and 'real solutions' in ConstCorp were, which in SaP terms would qualify them as 'strategists' (e.g. Johnson et al., 2003; Whittington, 2006; Jarzabkowski et al., 2007), and thereby also giving them the power to reject (or ignore) the practices and tools proposed by various (il)legitimate strategists. It may be worth noting how few alternative tools, models, or formalized practices (such as Project Portfolio Management) the managers included in their own storylines about the everyday 'doing' of strategy. Instead, the components of the 'strategy apparatus' resided within them as skill-sets acquired from managing challenging projects.

\section{CONCLUSIONS AND FUTURE STUDIES}

Our study lends weight to the relevance of a strategy agenda for the project-management field which acknowledges that project organizing provides a specific context and challenge for organizational strategizing. This is something that the external strategy consultants entering ConstCorp became acutely aware of too late. In the encounter with a group of project managers, they experienced the incongruity of trying to integrate mainstream strategy practices into project actualities in a large construction company. The resistance that we witnessed was not mobilized out of spite, but based on a clash between contradictory logics and habitus of two very different sets of practices (as summarized in Table 2). These particular project practices were customized for the day-to-day challenges of running construction projects. It would therefore certainly not be unfair to criticize the consultants for not acknowledging this in their preparations. Paying more attention to the specifics and 
actualities of these practices may have discouraged them from recycling the generic 'strategy package', which would probably have increased the possibilities of catalyzing any kind of reformed strategizing.

What would have been significantly harder to anticipate and prepare for was how project practices and mentalities in a much broader sense shape the approach towards strategy in the organization. These findings contradict the common view of projects as mere implementation sites of organizational strategy. Moreover, they challenge notions of the project-organization interface being a prioritized concern for organizational strategizing in PBOs. In the introduction, we discussed a tendency within project-management studies to view strategy as something that emerges (or not) through various combinations of interactions between the formal 'project' and 'organizational' levels. Such a view assumes the existence of clear boundaries and differences in need of translation, before any successful strategizing can be taking place. Our findings highlight, in contrast, that the strategizing pattern that integrated and created significant organizational outcomes in the PBO studied rested strongly upon overlapping practices and roles; making the boundaries of such an interface-space much more blurred and ineffectual. In order to pursue an 'integrative challenge' in regard to strategy and its execution in project management research, Söderlund and Maylor (2012:688) argue that it is necessary "to engage with both strategists and project managers who are struggling with everyday activities of getting their strategies and projects delivered successfully on time". However, our findings make a strong case for the need to reconsider this dichotomy altogether and consider overlapping roles and practices by which project managers may act as legitimate organizational strategists. That could, if anything, offer valuable contributions to an integrative challenge of strategy in the project-management field. 
The closeness to actual practices offered by our in-depth qualitative case study is a strength in terms of practical and theoretical relevance for various stakeholders in the construction industry as well as for other contexts which operate under similar circumstances. By the same token these findings need to be extrapolated to different contexts with caution. This article does not, however, aspire to be assessed in regard to how well it represents PBO contexts overall, but to the extent that it can trigger and inspire the framing of future studies along these lines within the project-management field as well as within $\mathrm{SaP}$ research. We imagine that such future studies would be characterized by further exploration of, for example, the circumstances and contexts by which project managers acquire competence and legitimacy to act as strategists and under which circumstances the boundaries between project practice and situated strategy practice are as fluid as in our case - also, under which circumstances project practices and mind-sets can be linked to significant organizational outcomes outside the formal boundaries of the temporally limited project. Our findings should also interest SaP researchers to further explore projects as 'training grounds' for upcoming organizational strategists (cf. Whittington 2006).

Inquires along these lines would, in our view, not only strengthen the understanding of strategy-as-it-is-practiced in PBOs, but also naturally integrate with, and extend the emerging agenda of project 'actualities' (e.g. Cicmil et al., 2006; Blomquist et al., 2010); offering a link between streams of research on management and organization studies (e.g. SaP) with project management. If there is any more general conclusion to be drawn from our case then it would be that in order to make such discoveries, it is necessary to leave aside the formal differences (pre)inscribed in project and organizational levels and focus foremost on the actors, their practices and their (inter)actions. 


\section{REFERENCES}

Adam, A. and Lindahl, G. (2017) Applying the dynamic capabilities framework in the case of a large public construction client, Construction Management and Economics, 35(7), 420-431.

Alvesson, M., and Kärreman, D. (2000) Taking the linguistic turn in organizational research challenges, responses, consequences. The journal of applied behavioral science, 36(2), 136158.

Alvesson, M., Hardy, C., \& Harley, B. (2008). Reflecting on reflexivity: Reflexive textual practices in organization and management theory. Journal of management studies, 45(3), 480501.

Ansoff, H.I. (1965) Corporate Strategy: An analytical approach to business policy for growth and expansion. Homewood: McGraw-Hill.

Artto, K., Kujala, J., Dietrich, P. and Martinsuo, M. (2008) What is project strategy? International Journal of Project Management, 26(1), 4-12.

Blomquist, T. and Packendorff, J. (1998). Learning from renewal projects: content, context and embeddedness. In: Projects as arenas for renewal and learning processes (37-46). Springer US.

Blomquist, T., Hällgren, M., Nilsson, A. and Söderholm, A. (2010) Project-as-practice: In search of project management research that matters. Project Management Journal, 41(1), 516. 
Biesenthal, C. and Wilden, R. (2014). Multi-level project governance: Trends and opportunities. International Journal of Project Management, 32(8), 1291-1308.

Bourdieu, P. (1990) The Logic of Practice, Stanford University Press, Stanford.

Brady, T., \& Davies, A. (2004). Building project capabilities: from exploratory to exploitative learning. Organization studies, 25(9), 1601-1621.

Chandler, A.D Jr. (1962) Strategy and Structure. Garden City, NY: Doubleday.

Chia, R. and MacKay, B. (2007) Post-processual challenges for the emerging strategy-aspractice perspective: Discovering strategy in the logic of practice. Human relations, 60(1), 217-242.

Cicmil, S., Williams, T., Thomas, J. and Hodgson, D. (2006) Rethinking project management: researching the actuality of projects. International Journal of Project Management, 24(8), $675-686$.

Czarniawska, B. (2004) Narratives in Social Science Research, Sage, Thousand Oaks, CA.

Davies, A., \& Brady, T. (2016). Explicating the dynamics of project capabilities. International Journal of Project Management, 34(2), 314-327. 
Engwall, M. (2003) No project is an island: linking projects to history and context. Research policy, 32(5), 789-808.

Eweje, J., Turner, R. and Müller, R. (2012). Maximizing strategic value from megaprojects: The influence of information-feed on decision-making by the project manager. International Journal of Project Management, 30(6), 639-651.

Fenton, C. and Langley, A. (2011). Strategy as practice and the narrative turn. Organization studies, 32(9), 1171-1196.

Floricel, S., Bonneau, C., Aubry, M. and Sergi, V. (2014). Extending project management research: Insights from social theories. International Journal of Project Management, 32(7), 1091-1107.

Furrer, O. Thomas, H. and Goussevskaia, A. (2008) The structure and evolution of the strategic management field: A content analysis of 26 years of strategic research. International Journal of Management Reviews, 10(1), 1-23.

Gann, D., Salter, A., Dodgson, M. and Phillips, N. (2012). Inside the world of the project Baron. MIT Sloan Management Review, 53(3), 63-71.

Golsorkhi, D., Rouleau, L., Seidl, D. and Vaara, E. (Eds.). (2010) Cambridge handbook of strategy as practice. Cambridge University Press.

Green, S., Larsen, C. D., and Chung-Chin, K. (2008) Competitive strategy revisited: 
Contested concepts and dynamic capabilities. Construction Management and Economics, 26(1), 63-78.

Hoskisson, R. E., Hitt, M. A., Wan, W. P. and Yiu, D. (1999) Theory and research in strategic management: Swings of a pendulum. Journal of Management, 25(3), 417-456.

Isabella, L. A. (1990). Evolving interpretations as a change unfolds: How managers construe key organizational events. Academy of Management journal, 33(1), 7-41.

Jarzabkowski, P., Balogun, J. and Seidl, D. (2007) Strategizing: The challenges of a practice perspective. Human relations, 60(1), 5-27.

Jarzabkowski, P. and Paul Spee, A. (2009). Strategy-as-practice: A review and future directions for the field. International Journal of Management Reviews, 11(1), 69-95

Johnson, G. Langley, A. Melin, L. and Whittington, R. (2007) Strategy as Practice Research Directions and Resources. Cambridge University Press, New York.

Löwstedt, M. and Räisänen, C. (2012). 'Playing back-spin balls': narrating organizational change in construction. Construction Management and Economics, 30(9), 795-806.

Löwstedt, M. (2015). 'Taking off my glasses in order to see': exploring practice on a building site using self-reflexive ethnography. Construction Management and Economics, 33(5-6), 404-414. 
Mantere, S. (2008) Role expectations and middle manager strategic agency. Journal of Management Studies, 45(2), 294-316.

Martinsuo, M., Gemünden, H. G. and Huemann, M. (2012). Toward strategic value from projects. International Journal of Project Management, 30(6), 637-638.

Martinsuo, M. (2013). Project portfolio management in practice and in context. International Journal of Project Management, 31(6), 794-803.

Maylor, H., Brady, T., Cooke-Davies, T. and Hodgson, D. (2006). From projectification to programmification. International Journal of Project Management, 24(8), 663-674.

Mintzberg, H. and Waters, J.A. (1985) Of strategies, deliberate and emergent. Strategic Management Journal, 6(3), 257-272.

Mintzberg, H., Ahlstrand, B. and Lampel, J. (2005) Strategy Safari: A Guided Tour Through The Wilds of Strategic Management. Simon and Schuster.

Morris, P. W. and Pinto, J. K. (2004) The Wiley guide to managing projects. Hoboken, NJ: John Wiley and Sons.

Morris, P. and Jamieson, A. (2005) Moving from corporate strategy to project strategy. Project Management Journal, 36(4), 5-18. 
Morris, P. W. and Geraldi, J. (2011) Managing the institutional context for projects. Project Management Journal, 42(6), 20-32.

Porter, M.E. (1980) Competitive strategy. Techniques for analyzing industries and competitors. New York: Free Press.

Porter, M.E. (1996) What is strategy? Harvard business review (November 1996)

Project Management Institute (2004) A Guide to the Project Management Body of Knowledge (PMBOK® Guide) - Third Edition. Newtown Square, PA.

Regnér, P. (2003) Strategy creation in the periphery: inductive versus deductive strategy making. Journal of management studies, 40(1), 57-82.

Räisänen, C. and Löwstedt, M. (2014). Stakes and struggles in liminal spaces: construction practitioners interacting with management-consultants. Engineering Project Organization Journal, 4(2-3), 123-133.

Schatzki. T.R. Cetina, K.K. and Savigny, E. (2001) The practice turn in contemporary theory. London: Routledge.

Seidl, D., \& Whittington, R. (2014). Enlarging the strategy-as-practice research agenda: Towards taller and flatter ontologies. Organization Studies 35(10), 1407-1421.

Shenhar, A.J., 2004. Strategic project leadership: toward a strategic approach to project management. $R \& D$ Management 34(5), 569-578. 
Slack, N., and Lewis, M. (2002). Operations strategy. Pearson Education

Srivannaboon, S. and Milosevic, D. Z. (2006) A two-way influence between business strategy and project management. International journal of project management, 24(6), 493-505.

Styhre, A. (2006). The bureaucratization of the project manager function: The case of the construction industry. International Journal of Project Management, 24(3), 271-276.

Söderlund, J., Hobbs, B. and Ahola, T. (2014) Project-based and temporary organizing: Reconnecting and rediscovering. International Journal of Project Management, 32(7), 10851090.

Söderlund, J. and Maylor, H. (2012) Project management scholarship: Relevance, impact and five integrative challenges for business and management schools. International Journal of Project Management, 30(6), 686-696.

Tsoukas, H., and Chia, R. (2002) On organizational becoming: Rethinking organizational change. Organization science, 13(5), 567-582.

ul Musawir, A., Serra, C. E. M., Zwikael, O., \& Ali, I. (2017). Project governance, benefit management, and project success: Towards a framework for supporting organizational strategy implementation. International Journal of Project Management, 35(8), 1658-1672. 
Unger, B. N., Kock, A., Gemünden, H. G., \& Jonas, D. (2012). Enforcing strategic fit of project portfolios by project termination: An empirical study on senior management involvement. International Journal of Project Management, 30(6), 675-685.

Vuori, E., Artto, K., \& Sallinen, L. (2012). Investment project as an internal corporate venture. International Journal of Project Management, 30(6), 652-662.

Winch, G. M. (2014). Three domains of project organizing. International Journal of Project Management, 32(5), 721-731.

Winch, G.M. and Leiringer, R. (2016) Owner project capabilities for infrastructure development: A review and development of the "strong owner" concept. International Journal of Project Management, 34(2), 271-281.

Winter, M., Smith, C., Morris, P. and Cicmil, S. (2006) Directions for future research in project management: The main findings of a UK government-funded research network. International journal of project management, 24(8), 638-649.

Whittington, R. (2003) The work of strategizing and organizing: For a practice perspective. Strategic Organization, 1(1), 119-127.

Whittington, R. (2004) Strategy after modernism: recovering practice, European Management Review, 1(1), 62-68. 
Whittington, R. (2006) Completing the practice turn in strategy research. Organization studies, 27(5), 613-634.

Whittington, R. (2007) Strategy practice and strategy process: family differences and the sociological eye. Organization studies, 28(10), 1575-1586.

Young, R., Young, M., Jordan, E. and O'Connor, P. (2012) Is strategy being implemented through projects? Contrary evidence from a leader in New Public Management. International Journal of Project Management, 30(8), 887-900. 